Pobrane z czasopisma Annales H - Oeconomia http://oeconomia.annales.umcs.pl Data: 26/04/2023 16:27:08

DOI:10.17951/h.2017.51.2.19

A N N A L E S
UNIVERSITATIS MARIAE CURIE-SKŁODOWSKA
LUBLIN - POLONIA
VOL.LI, 2
SECTIOH H

Kozminski University, College of Management and Finance/Logistics and Procurement Centre *Institute of Logistics Innovation/Logistics and Procurement Centre

\author{
MIROSŁAW ANTONOWICZ \\ maaw@kozminski.edu.pl \\ ARKADIUSZ ŻUREK* \\ arkadiusz.zurek@instytutintl.pl
}

\title{
Comments on the Risks of Supply Chains in Trade with the East
}

Uwagi o ryzykach łańcuchów dostaw w handlu ze Wschodem

Key words: supply chain; risk; trade

Słowa kluczowe: łańcuch dostaw; ryzyko; handel

JEL codes: F6; M3; R4

\section{Introduction}

Risk is a common phenomenon in market driven economies. It arises in the decision-making process and is bounded with this process due to uncertainty [Murray 2009 , p. 3]. Operations under risky conditions are also natural for every trade process, both in the sale and the purchase and, as such, are perceived as negative occurrence [Krzanowska 2016, following Zacher and Kiepas 1994, p. 14]. They are associated either with hazard, or hazard and opportunity occurring together [Ślabska et al. 2016, following Bernstein 1995, p. 3]. There is also offered a variety of typologies of the risk of supply chains ${ }^{1}$. This is the reason why Polish entrepreneurs, with a view to their oblivion to or insufficient knowledge of the East trade realities and environment,

\footnotetext{
1 E.g. risk of supply chain on market B is divided into decision-making risk, supplier-recipient cooperation risk, dependency risk, outsourcing and offshoring risk [Wieteska 2011, pp. 78-107].
} 
may be exposed to a variety of obstacles. International supply chains are particularly vulnerable to a variety of interference [Chopra and Sodhi 2004, pp. 53-61]. The present paper constitutes an attempt to identify the risk in trade with the East. In addition, it presents essential conditions in trading with the East and offers viable ways of managing the risk involved in this trade.

\section{Risk in supply chains}

Supply chains are currently a dynamic concept of the business or businesses management [Kruczek and Żebrucki 2011, p. 355]. A supply chain can take the form of a group of businesses conducting joint operations which are crucial to meet the demand for particular products within the entire chain (net) of the flow of goods from the procurement of raw materials to the final product delivery to the end user [Coyle et al. 2002, p. 31]. A supply chain connects potential customer markets and delivery markets, i.e. clients and suppliers [Zakrzewska 2017, p. 7]. Globally operating businesses, in particular, are exposed to risk ranging from the fluctuations in both the price of merchandise and exchange rates, to wars and natural disasters. This translates into disturbances in the supply chain and financial results of companies, as the research by $\mathrm{PwC}^{2}$ into the risk management in supply chains reveals. The outcomes of the research indicate correlations between the interference in supply chains and the financial results of businesses. The research conducted by consultants from $\mathrm{PwC}$ and the MIT Forum for Supply Chain Innovation investigated the total of 209 businesses of global character. Their analysis referred to the functioning of a supply chain and the effect of interference in this area on the financial results of the company. The main conclusions from the analysis are the following $[P w C$ and the MIT Forum for Supply Chain Innovation. Making the Right Risk Decisions to Strengthen Operations Performance, 2013]:

1. All interference in the functioning of a supply chain translates directly into the operative effectiveness of the company.

2. Companies which have all competencies to successfully manage supply chains and risks are more resistant to unexpected interference.

3. Businesses which establish flexible supply chains are less vulnerable to any kind of risk.

4. Businesses which invest in the programme for the risk management per segment are more resistant to change.

2 PricewaterhouseCoopers $(\mathrm{PwC})$ - a global network of businesses which render accounting, auditing and counselling services; set up in 1999 as a result of a merger between Price Waterhouse and Coopers \& Lybrand. It is composed of formally independent businesses operating in every country where the company is present and are associated under the global coordinating PricewaterhouseCoopers International Limited (PwCIL) based in London. 
Businesses which conduct international operations, with a view to the complexity of trade transactions, are particularly susceptible to negative consequences of risk. Companies, in order to counteract such situations, must conduct the analysis of the risk arising in their supply chain and implement adequate methods to manage it. With regard to the intensifying international exchange and growing globalisation, evident in outsourcing or offshoring, the complexity of supply chains structure and the level of advancement, together with the level of risk, are increasing [Szymczak 2014, p. 73]. The necessity of the risk management is becoming urgent, especially if the risk arises ever more often in complex networks of co-dependent entities. The growth of supply chains increases the level of possible risk [Nowacki 2014, pp. 2-9]. While conducting the risk analysis in the context of globalisation, one has to remember about the occurrence of phenomena which are beyond the trading parties' influence. Businesses make investments, look for new markets for their products as well as new markets of suppliers - activity which, in the market economy is understood as necessary to stimulate growth and development. However, the bigger the distance between business partners, the higher the probability of the occurrence of direct and indirect risk which may lead to particular negative results for either or both of them. That is why, when doing the risk analysis for a supply chain, it is not only essential to ensure the management of the consequences of a mishap; it is also vital to introduce proper mechanisms to allow for the mitigation of the negative consequences, if not for their total blockade. Risk, for a business in the market economy has become an objective phenomenon. Nonetheless, it affects different spheres of business operations to varying degrees. Therefore, the risk of a supply chain may assume the form of inappropriate strategy, wrong decisions, far-from-optimum configuration of the logistic system, etc. All these forms of risk may arise from, among others, the number of subjects in the supply chain, accessibility to major transport hubs or the number and type of distribution channels [Kulińska 2007, p. 19].

\section{Types of risk in the supply chain}

Relevant literature distinguishes various typologies of risk. Biegański divides risk into two basic types [Biegański 2001, pp. 9-15], i.e. the strategic risk which affects competitiveness and is, in the long term, related to the structure of ownership and capital involvement, business profile, management system, organisational structure. The other type of risk is the operative risk which is further divided into the risk within financial sphere and the risk within technical-organisational sphere. Lusztyn [www.finanse.info.pl/artykuły] distinguishes the following types of risk in business operations: business (reputation, competition, etc.), financial (currency, interest rates), cash flow (insolvency of business parties, concentration, etc), and operational (natural disasters, professional skills of employees, etc). Risk, by others, is also divided into two basic categories, i.e. strategic risk and operational risk 
[Jennison 2007, pp. 22-23] - as presented in Table 1. Kaczmarek has offered an interdisciplinary typology of risk [Kaczmarek 2010, p. 73] and distinguishes such areas of risk as politics, economy, law, culture, etc ${ }^{3}$.

Table 1. Allocation of risk

\begin{tabular}{|c|c|}
\hline Strategic risk & Operational risk \\
\hline Political & Financial \\
\hline Economic & Legal \\
\hline Social & Professional \\
\hline Technological & Physical \\
\hline Legislative & Contractual \\
\hline Environmental & Environmental \\
\hline
\end{tabular}

Source: Authors' own study, following: Jennison [2007, p. 23].

As regards business activity, risk is divided into production risk, trade risk and financial risk. For the present discussion, it is the trade risk - understood as the external uncertainty - that matters most. Trade risk may be divided into market risk (fluctuation of prices and exchange rates), contingencies (e.g. failure of equipment, Acts of God), purchase risk (e.g. unreliable supplier, low quality product), sales risk (e.g. unstable demand, competition) and transportation risk (e.g. product in-transit defects, lost items). Trade risk is of particular significance due to both the ongoing transformations in the functioning of trade and the globalisation of the economy which together indicate the growing importance of trade as the link binding the partners of business exchange. According to Szczepankiewicz [2011, p. 100], trade as the player in a supply chain, performs three integrated functions, i.e. the function of the coordinator, the advisor, and the partner which all account for the identification of demand and the creation of effective logistic transformation processes, as well as for adding value in the process of logistic flow. With respect to the above, as rightly indicated by Małyszek [2015, p. 918], the literature most often analyses the four categories of risk which are related to the areas of logistic flow and embedded within the context of other threats. The categories of risk interpreted in this way are presented in Figure 1. The supply area-related risk in a supply chain results from unwelcome events which adversely affect the ability of a business to satisfy its clients' expectations. Risk in the operational area refers to unwanted events in the production/service delivery and exploitation of assets. Risk within the demand management area signifies the fluctuation of the demand, disturbances in the distribution processes which deter potential clients from placing orders and/or cause doubts as for the amount of such orders. These three categories of risk interact and may overlap adding in negative impact. Additionally, each area of the logistic flow is exposed to the risk of unwanted circumstances beyond the control of the supply

3 Generally, Kaczmarek presented 17 categories of risk, such as the risk of force majeure, political risk, civilization and culture risk, new technologies and ecology connected risk, insurance risk. 
chain participants (security risk). This risk may adversely affect, among others, transportation processes or value adding processes due to the dependency of the supply chain effectiveness on the quality of infrastructure resources.

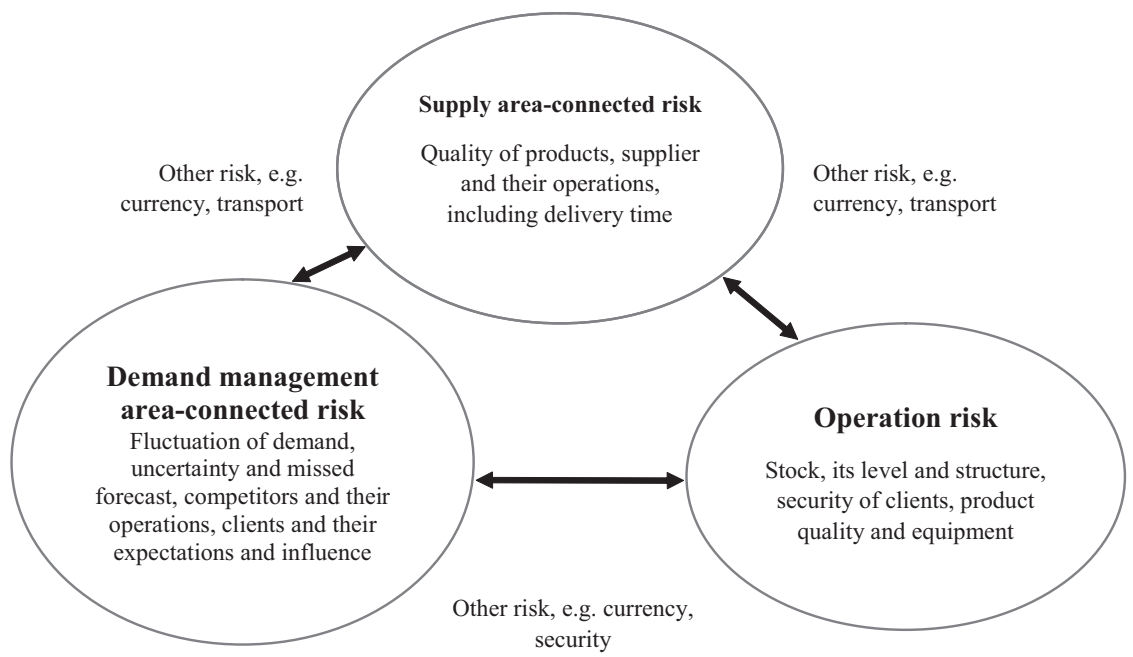

Figure 1. Types of risk in the supply chain

Source: Authors' own study on the basis of Małyszek [2015, p. 919], Wieteska [2011, p. 74], Manuj and Mentzer [2008, pp. 192-223].

For business operations within international supply chains a significant hazard occurs in micro-environment. It is the source of a variety of risks for both business operations and business decisions. Risk factors are located in many environments, such as political, economic, socio-cultural, legal, environmental and technical-technological. In order for the risk management to bring expected results, it should be conducted only after the factors leading to risk in supply chains have been properly recognized [Gaschi-Uciecha 2014, p. 124].

\section{Requirements of trade with the East with regard to the risk issue - selected aspects $^{4}$}

Polish export has been one of the power engines for the Polish economy for a few years. Positive trade balance has been noted since 2014. Export dynamism has, to a large extent, its reflection in the trade with the $\mathrm{CIS}^{5}$ and such countries as Belarus, Kazakhstan, Russia, Ukraine and China, too. A lot of Polish entrepreneurs look at

4 Based on the authors' own experience from trade and business contacts.

5 CIS - the Commonwealth of Independent States. 
Eastern markets through a set of stereotypes and political situation. In the face of difficulty to foresee political environment and its influence on business, eastward expansion raises many doubts among Polish businesspeople. Distinct law, culture and customs practised by a foreign business may be the source of concern. For many Polish entrepreneurs, the idea of "Eastern market" is parallel to solely Russian market. However, business potential of the Eastern market refers also to such countries as Moldova, Belarus, Ukraine, Kazakhstan or Uzbekistan. Developmental potential for the Polish export is conspicuous as shown on the example of the Polish food export to the Czech Republic and Russia. Poland exports to the Czech Republic - with the population of about 10 million - the same amount of grocery products as it exports to Russia with its population of 140 million. This discrepancy is caused, among others, by the imposed embargo and sanctions or protective laws of their internal market, and, finally, by bureaucratic barriers in the trade with Russia. Products which are sold in the East are required to have certificates, such as GOSTR ${ }^{6}$. Kazakhstan and Belarus, together with Russia, form the Euro-Asian Union but do not incur sanctions. Polish businesses which operate in the East overcome these difficulties (e.g. they cut down operations and investments, raise prices, select contractors) and do not intend to leave these markets. Such policies are confirmed by the attitude expressed by Polish businesses ${ }^{7}$. Devaluation of the Ukrainian currency has been the most serious problem in the trade with Ukraine. It is worth mentioning that the Russian market is the biggest and most prestigious market which has the biggest business potential. Russia and other countries which represent the region are an opportunity for, among others, Polish construction. A significant factor which helps to develop construction market are sports events hosted by Russia, e.g. next year's world championship FIFA World Cup 2018. Such events require the construction of new sports facilities, hotel base and road infrastructure, and this is why the demand for construction materials has risen. As for the Russian market, Polish investments are nowadays concentrated in 3 areas $-82 \%$ of them are located in the Moscow, Petersburg, and Kaliningrad areas. Purchasing power of the Moscow metropolitan area is bigger than the Czech,

6 Certificate of Compatibility GOST R is the fundamental document which confirms that a given product does not violate Russian norms of GOST. On its basis production gets PCT mark. GOST norms are the documents established by Federal Agency for Technical Regulation and Metrology (Rosstandart). Based on the binding GOST norms, research is done which serves as the basis for the decision if a given product meets quality and safety standards. When analysed products meet all the requirements of GOST, they receive the Certificate of compatibility GOST R which, subject to legal requirements, can be issued for a year and up to 3 years. The Certificate is issued both for series production as well as for a particular batch of goods.

7 "We have been in the East for over 10 years. Our brands are known there. That is why, despite difficult situation on these markets, we intend to stay in Russia and Ukraine" - declares Magdalena Stefańska-Lotkowska from LPP, the biggest Polish clothing business. Piotr Mikrut, CEO of Śnieżka, producer of wall paints and lacquers, is in line with her when saying: "We do not give up our development in the Ukrainian market". Also, Asbis - the company distributing IT equipment - despite limitations on their operations, does not agree to give up their presence on this market. Plastic packaging producer - Plast Box - is another one who has decided not to withdraw from the Eastern market. On the contrary, they are staying on the volatile Eastern market and already showing their determination to continue for as long as necessary. 
Slovak and Hungarian taken together. The three regions mentioned above are inhabited by 26 million consumers. Apart from them, we should remember about the remaining Russian market, its great potential and clients living far from big cities in the European part of Russia. There is also an important and wealthy Siberian market with the population of 1 million people in each of a few major cities and, above all, Novosibirsk with 1.45 million people - the largest city among them in the whole region. The countries which came into being following the collapse of the USSR are usually associated with corruption, crime and backwardness. Irrespective of negative phenomena, they are also the countries of considerable potential. Cultural environment in the Eastern markets is more important than in other markets. This means that an entrepreneur who enters Eastern markets and deliberately neglects their cultural environment may be doomed to failure. When one decides to operate on the Belarusian, Russian, Ukrainian, Kazakh, or Chinese market, one needs to find out about their target consumer, especially their mentality and culture. In the post-USSR countries and in China the change in mentality has not really occurred. One cannot truly gain ground in these markets with no knowledge of their peoples' culture, mentality, tradition and their perception of the world. Disregard for market research and information about business culture as well as the consumer behaviour significantly contributes to the overall risk for an investor who wishes to start cooperation with the East in its broad sense. It is also worth emphasizing that an Eastern client is a loyal client. Once we win such a client for us, they will recommend us to the people they know. Thanks to such word-of-mouth recommendation we may count on long-term relationships. Then there comes the bond between a consumer and the brand. It is an important statement. It is best if there is someone, in the Eastern market, who can recommend us. Ideally, this should be a local partner. If we get introduced by a Russian or Chinese partner or by a Russian or Chinese business, then our business relations are more transparent. The method of step by step is recommended to use. You have to work hard to gain trust. There is little chance for a business to succeed if there are no recommendations nor a well-balanced, tough and consistent approach to business and negotiations as well as understanding and acceptance of principles and methods of conducting business by an Eastern partner. Poland has always been the bridge between the East and the West and this is the role to continue playing and rely on.

\section{Conclusions}

Eastern markets have huge potential for development. That is why it is the Polish entrepreneurs' interest to establish strong market position and brand there as has already been accomplished by, among others, Eveline Cosmetics, Selena and Maspex. Russia alone is a very good market thanks to its size and huge internal market. There is no real crisis but only the imagined crisis in our entrepreneurs' heads. They with- 
hold operations because they are wary of the future. The businesses which only try to outlast the crisis or adopt the wait-and-see approach to this unstable period may face certain problems with restoring their market position. Businesses which actively seek an alternative approach during a crisis, ensure much stronger future position on the market. Polish entrepreneurs are already on the lookout for new solutions, and Eastern markets are one of them.

\section{Bibliography}

Biegański, M., Hedging i nowoczesne ustugi finansowe, AE Publishing, Poznań 2001.

Bernstein, P.L., Risk as a History of Ideas, "Financial Analysts Journal", vol. 51, no. 1, 1995, pp. 7-11.

Chopra, S., Sodhi, S., Managing Risk to Avoid Supply-Chain Breakdown, "MIT Sloan Management Review", vol. 46, no. 1, 2004, pp. 53-61.

Coyle, J.J., Bardi, E.J., Langley, C.J.J., Zarządzanie logistyczne, PWE, Warsaw 2002.

Gaschi-Uciecha, A., Istota ryzyka w procesach logistycznych, "Zeszyty Naukowe Politechniki Śląskiej”, no. 70, Gliwice 2014, pp. 119-129.

Jennison, B., Zarządzanie ryzykiem w sektorze publicznym, Ministry of Finance RP, Warsaw 2007.

Kaczmarek, T.T., Zarzadzanie ryzykiem. Ujęcie interdyscyplinarne, Difin, Warsaw 2010.

Kruczek, M., Żebrucki, Z., Doskonalenie struktury tańcucha dostaw z wykorzystaniem koncepcji lean, "Logistyka", no. 2, 2011, pp. 355-362.

Krzanowska, K., Ryzyko w projekcie „Executives Hotel” realizowanym przez Grupę Nowy Styl, ALK, Warsaw 2016.

Kulińska, E., Zarządzanie ryzykiem w tańcuchu dostaw, "Logistyka”, no. 1, 2007, pp. 18-21.

Lusztyn, M.G., Value at Risk - zarządzanie ryzykiem w przedsiębiorstwie, www.finanse.info.pl/artykuly (access: 5.02.2017).

Małyszek, E., Wybrane aspekty ryzyka w zarządzaniu łańcuchem dostaw, [in:] Innowacje w zarządzaniu i inżynierii produkcji, vol. 1, R. Knosala (ed.), PTZP, Opole 2015, pp. 914-925.

Manuj, I., Mentzer, J.T., Global Supply Chain Risk Management Strategies, "International Journal of Physical Distribution \& Logistics Management", vol. 38, no. 3, 2008, pp. 192-223.

Murray, A., PRINCE2. Skuteczne zarzadzanie projektami, Outperform Ltd., UK 2009.

Nowacki, F., Analiza ryzyka w tańcuchu dostaw i zarządzania nim w aspekcie międzynarodowym, "Gospodarka Materiałowa i Logistyka", no. 4, 2014, pp. 2-9.

PwC and the MIT Forum for Supply Chain Innovation. Making the Right Risk Decisions to Strengthen Operations Performance, 2013.

Ślabska, B., Andruczyk, M., Przybyszewska, K., Feliniak, A., Zarzadzanie ryzykiem w procesie zakupowym, ALK, Warsaw 2016.

Szczepankiewicz, W., Funkcjonowanie sektora handlu w tańcuchach dostaw, Difin, Warsaw2011.

Szymczak, M., Offshoring a rozwój łańcuchów dostaw, AE Publishing, Poznań 2014.

Wieteska, G., Zarządzanie ryzykiem w tańcuchu dostaw na rynku B2B, Difin, Warsaw 2011.

Zacher, L.W., Kiepas, A., Spoleczeństwo a ryzyko, Education Foundation TRANSFORMACJE, Warsaw 1994.

Zakrzewska, M., Analiza łańcucha dostaw telewizorów Sony Polska, ALK, Warsaw 2017. 


\section{Comments on the Risks of Supply Chains in Trade with the East}

The authors of the article discussed the issue of risk in supply chains. They clarified the essence of supply chain and the risk related to the functioning of the supply chain. Basic risks in supply chains were presented. The issue was set in the context of trade with the East. Taking up the issues was the result of personal experience in the conduct of business on the Eastern markets in the area of enforcement activities and the sale of services in the logistics services. In conclusion, despite the adverse circumstances of political, economic and cultural nature of the risks, the authors recognized it is worth looking for alternatives of development on the Eastern markets.

\section{Uwagi o ryzykach lańcuchów dostaw w handlu ze Wschodem}

W artykule zostało przedstawione zagadnienie ryzyka w łańcuchach dostaw. Autorzy wyjaśnili istotę łańcucha dostaw, wskazali ryzyka związane z funkcjonowaniem łańcucha dostaw oraz przedstawili podstawowe rodzaje ryzyka w łańcuchach dostaw. Problematyka została osadzona w kontekście handlu ze Wschodem. Jej podjęcie było efektem osobistych doświadczeń w prowadzeniu działalności biznesowej na rynkach wschodnich w obszarze działań wykonawczych i sprzedaży usług, w tym usług logistycznych. W konkluzji, mimo niekorzystnych uwarunkowań natury politycznej, ekonomicznej i ryzyk natury kulturowej, autorzy uznali, że warto szukać alternatyw rozwojowych na rynkach wschodnich. 